\title{
The Religion, Globalisation and Education Triangle: Provincialising the Contemporary Discourse
}

\author{
Miri Yemini (Tel Aviv University)
}

This essay deals with the role of religion in globalised, national educational spaces. I argue that religion, which in Western education milieus is generally perceived as a marginal component of contemporary schooling and detached from the wider educational contexts of state schools, is becoming more relevant in many educational institutions. This is happening both as a result of the increasing mobility of families generating a presence of sustainable diaspora communities and as an outcome of globalised communities seeking new anchors for their everchanging realities (Agbaria, 2019). Since much of the writing on religious education is critical of its incorporation into state schooling (e.g., Sabbagh, 2019; Elgad-Klonsky \& Tamir, 2019), and occupies the hegemonic Western stance, I hereby discuss some empirical findings that show how religion may actually integrate with global processes and even lead them by re-framing the existing system of values and reshaping spatial and social settings in schools. Religion has always been a common source of selfidentification that enables the sharing of worldviews and values, and the development of solidarity in large communities. Religion has functioned for centuries as the maker and designer of relationships; but it has been argued that globalisation is reorganising the global sphere and consequently also the way people practice religion. The main claim in this argument is that secular trends are becoming more dominant in general, alongside secessionist tendencies of communities that oppose modernity and the effects of globalisation. Discourse regarding religious communities and the role of religion is sometimes patronising, assuming religious education as an anachronistic remnant of the old world. This tendency comes alongside writings that warn of the rise of religious communities and especially the impact of education on fundamentalism and religious extremism, especially in regard to Islam (Yemini, 2018).

Therefore, in conjunction with this issue of On_Education, I seek to offer a different perspective on the intersection of globalisation and religion through an emic analysis of a unique case: a Jewish religious school in Israel that proactively adopts the global ideology, expressed mainly through teaching all subjects in English as well as utilising a pedagogical approach based on project-based learning of globally oriented issues.

This elementary school located in a central city is part of Israel's state Jewish religious sector. The school was founded to replace a failed school that was running on the spot and was closed due to low enrolment. Because the neighbourhood that the school serves is mostly populated by religious Jews who usually send their children to schools in remote neighbourhoods, the principal of the new school was required to develop a unique focus for the school. The focus on the global dimension and English as a medium of instruction was chosen because the neighbourhood has a significant population of immigrants from the United States and other English-speaking countries. Indeed, this school claims to be the only one operating in a unique pedagogy that includes English teaching of all subjects, the presence of two classroom educators - one who speaks Hebrew and one English - and a project-based curriculum. Several observations and dozens of in-depth interviews were conducted at the school, which seems to counteract the common tendency towards an inward focus expressed in recent decades by the Israeli Jewish religious community, having chosen instead to incorporate global principles into its teaching and learning processes.

The main argument that has been repeated among all school stakeholders, including the management team, teachers, parents, and superintendents, is that religion and globalisation are capable of mutually evolving and creating complex interactions that transcend the boundaries of the commonly recognised dichotomy between global and local dimensions in education. Stakeholders of the school in question argued that the secular world is in a hurry to classify them as closed and isolated, when they see themselves as being selective, choosing and adopting certain parts of the modern and global world while consciously opting out of and recalculating other parts. In fact, contrary to popular belief that considers religious schools conservative and submissive to traditional values and thus contributing to the closed-off nature of their communities, most interviews and observations gathered at this school indicated a high level of agency demonstrated by all involved. Scholars usually attribute such agency to 
trends that encourage self-expression and individualism that Western education boasts, while often neglecting the role of agency in closed religious communities.

In addition to the role of agency, it is also worth noting the value selection process applied in this religious school. The school focuses on the global dimension in education as a reflection of its contribution to the imagined future of the graduates, as well as to their alignment with the values of religious education, which constitutes the final arbiter in the selection process. Yet while the willingness to follow religious law and orders lies at the heart of religious education, it is not monotonous but rather multifaceted, involving many considerations. Thus, the nature of community, and living arrangements are all taken into account when choosing to embrace certain issues or omit them from the curriculum. Thus, although the 'Western perspective' often considers the religious education system as homogeneous, applying one set of considerations, we see here the many nuances that are included in the concrete pedagogical development and implementation processes.
The almost frivolous fear of integrating religious education into the public-school agenda partially stems from the fact that traditional education was essentially religious. Most notably, the Western world's opposition to Muslim religious schools stands out, but public Jewish schools in Israel are also under attack. In fact, religious education is often considered as such only if it is not Christian, while the Christian sections of public education in Europe are not categorised as such. As the globalisation process and immigration increasingly change the social and ethnic fabric of public schools in the Western world, Christian dimensions of public schools are often categorised as fostering family or community values, while in fact the 'others' are required to embed Christian traditions without the possibility of demonstrating agency and choice.

To conclude, the intersection between religion and globalisation in the education domain should be reconsidered, using various multifocal frameworks, to better address the changing reality in schools. ${ }^{1}$

\section{References}

Agbaria, A. K. (2019). Religion and the global middle class: Towards a new research agenda. Discourse: Studies in the Cultural Politics of Education, 40(5), 734-742. https://doi.org/10.1080/01596306.2019.1602307

Elgad-Klonsky, S., \& Tamir, E. (2019). An ideological clash of worldviews in State religious schools in Israel. International Journal of Educational Development. Advance online publication. https://doi.org/10.1016/j.ijedudev.2019.102083

Sabbagh, C. (2019). "Glocal" neoliberal trends in Israeli education: The case of religionization. International Journal of Educational Development, 68, 88-95. https://doi.org/10.1016/j.ijedudev.2019.05.004

Yemini, M. (2018). Global/local nexus: Between global citizenship and nationalism in a super-diverse London school. International Studies in Sociology of Education, 27(2-3), 271-287. https://doi.org/10.1080/09620214.2018.1429946

\section{Recommended Citation}

Yemini, M. (2020). Religion, globalisation and the education triangle: Provincialising the contemporary discourse. On Education. Journal for Research and Debate, 3(7). https://doi.org/10.17899/on_ed.2020.7.9

About the Author

Miri Yemini is an established comparative education scholar tenured at Tel Aviv University, who explores internationalisation of education in schools and higher education, global citizenship education, and education in conflictridden societies, with a particular focus on the learning experiences of children. She has also contributed substantially to research on the involvement of external actors in schools. Most of her research focuses on Israel, but she has also worked and published on education and youth issues in Germany and the UK. In addition, Dr. Yemini is an active member of CIES, CESE and BAICE, and she is a President Elect for the Israeli Comparative Education Society. During 2013-2015, she served as a head of the Sociology of Education Section at the Israeli Sociology Association. Dr. Yemini has published extensively in the following publications, among others: Educational Administration Quarterly, Educational Management Administration \& Leadership, Comparative Education Review, Teaching and Teachers Education, Compare, Discourse: Studies in the Cultural Politics of Education, Journal of Studies in International Education, Globalisation, Societies and Education, Urban Education, Educational Review. 
${ }^{1}$ The empirical data discussed in this essay was collected by Mr. Itamar Rozelfled as part of his MA thesis. 